\title{
EFFECT OF RADIANT INSECTICIDE ON THE BIOLOGY AND EGG'S HATCHABILITY OF CHRYSOPERLA CARNEA (STEPHENS) (NEUROPTERA: CHRYSOPIDAE)
}

\author{
SHAALAN, H.S. AND MERVAT A.A. KANDEL
}

Plant Protection Research Institute, ARC, Dokki, Giza

(Manuscript received 12 November 2009)

\begin{abstract}
Effect of Radiant (insecticide) on developmental stages and reproduction of Chrysoperla carnea (Stephens) resulted from treated eggs were estimated. The $\mathrm{LC}_{25}, \mathrm{LC}_{50} \mathrm{o}$ and $\mathrm{LC}_{95}$ values for radiant-treated $1-2$ days old eggs were $0.625,1.875$ and 27.323 $\mathrm{ppm}$, respectively. The results indicated that the percentage of hatchability, larvae formed cocoons and adult emergence were differently and high affected by different concentrations, when reared on two preys, Pectinophora gossypiella (Saund.) eggs and Aphis craccivora nymphs. The obtained results showed a prolongation in (larval+cocoon) period resulted from eggs treated with $\mathrm{LC}_{50}$ and reared on $P$. gossypiella or $A$. craccivora compared to control, this period was estimated by 19.5 and 17.8 days, respectively, compared to 16.9 and 15.9 days for the controls. The larval feeding capacity of $C$. carnea highly differed significantly between larvae resulted from treated egg and fed on $P$. gossypiella eggs or $A$. craccivora nymphs compared to control. The results indicated also high shortening in longevity of females and males and high reduction in total eggs laid and percentage of hatchability.

Key words: Radiant $12 \%$, predator C. carnea, preys $P$. gossypiella and Aphis craccivora
\end{abstract}

\section{INTRODUCTION}

The common green lacewing, Chrysoperla carnea (Stephens) is one of the most common arthropod predators (Tauber et al., 2000). This predator has been observed associated with a wide prey range including aphid, eggs and neonate larvae of ; Lepidopteran insects such as, Pectinophora gossypiella, Earias insulana (Boisd.) and ; Spodoptera littoralis (Boisd.), scale insects, whiteflies, mites and other soft bodied. insects.

The insecticide spinosad has been shown to be an effective pest control agent (Brickle et al., 2001), particularly for control of lepidopteran insect pests (Wanner et al, 2000). Many authors studied the effect of spinosad on C. carnea .Of these Medina et al. (2001) demonstrated that spinosad had little effect on $C$. carnea adult longevity and fecundity with no impact on eggs. While in 2003, Medina et al. reported that azadirachtin and diflubenzuran were highly toxic to $C$. carnea third instar larvae. In 2003, Medina et al. observed that spinosad shortened the life span of $C$. carnea and Yoo and Kim (2000) indicated a reduction in fecundity of predatory mites. 
The present investigation were cared out to study the effect of spinetoram (Radiant) compound on the egg hatching and development of immature stages as well as adult longevity and fecundity of the Chrysoperla carnea aduilts. Eggs and adults of predator were çollected from cotton field in Qalubia Governorate.

\section{MÄTERIALS AND METHODS}

The àdults of $C$. carnea were collected from cotton fields and confined in chimney glass, covered with a piece of black muslin as a site for ovipostion, Eggs laid were collected and kept until hatching. The neonate larvae were divided into two groups, the first was reared on eggs and larvae of the pink bollworm (PBW), P. gossypiella and the second was reared on the aphid, Aphis craccivora for two generation.

Insects used as prey:

\section{P. gossypiella:}

The newly hatched larvae of PBW used in these experiments were reared in the laboratory on semi-artificial diet inside glass vials $(2 \times 7 \mathrm{~cm})$ according to Rashad and Ammer (1985).

\section{Aphis craccivora (Koch)}

The broad been (Vicia faba L.) was planted in laboratory under room conditions and the seedling were infested by the aphid, Aphis craccivora.

\section{Insecticides used:}

Common name: Radiant SC12\% (spinetoram), it is a new product from spinosyns group with the same mode of action, it is a trademark of Dow Agro Science Co. The recommended rate was $35 \mathrm{ml}$ add to $200 \mathrm{~L}$ water/feddan.

\section{Procedure:}

To study the ovicidal activity of Radiant against eggs of C. carnea, serial concentrations, in water, were prepared. Six concentration $(12,6,3,1.5,0.75$, and $0.375 \mathrm{ppm}$ ) for Radiant were freshly prepared for the stock solution of $0.5 \mathrm{ml} / 1$ liter water.

\section{Treatment of $C$. carnea eggs:}

The strips of muslin cloths with attached eggs of $C$. carnea (one-two days old) were dipped into the afore-mentioned selected concentrations of Radiant.The control eggs were dipped into water only. The strips were left for 1-2 hrs until drying, kept at the rearing condition and examined daily until hatched. $\mathrm{LC}_{25}, \mathrm{LC}_{50}$ and $\mathrm{LC}_{90}$ were determined and recorded.

Newly hatched larvae of $C$. carnea resulted from eggs treated with the dose of $L_{50}$ of Radiant were kept, individually, in glass vials stoppered with cotton-wool. One group was fed on eggs of PBW and another group was fed on Aphis craccivora nymphs. The 
vials were examined daily until the cocoons were formed to estimate the total consumption of prey and larval and cocoon durations for each group. The preovipostion, ovipostion and post-ovipostion periods as well as number of deposited eggs and percentage of hatching were also estimated. All studies were carried out at $26 \pm 1{ }^{\circ} \mathrm{C}$ and $70-80 \%$ R. H.

Statistical analysis:

One way analysis of variance (ANOVA) and Duncan's multiple range test of means were used (Duncan's, (1955).

\section{RESULTS AND DISCUSSION}

\section{Ovicidal effect of Radiant:}

The $\mathrm{LC}_{25}, \mathrm{LC}_{50}$ and $\mathrm{LC}_{95}$ values for $C$. carnea eggs ( 1-2 days old ) treated with radiant $12 \%$ were $0.625,1.875$ and $27.323 \mathrm{ppm}$, respectively, (Table 1 ).

The hatchability percentages of eggs increased as the concentrations of Radiant decreased. They ranged between 0.0 and $83.3 \%$ compared to $98 \%$ for untreated eggs.

Percentages of larvae formed cocoons:

Data in Table (1) show the percentages of hatched larvae developed and formed cocoons when reared on $P$. gossypiella or A. craccivora. Such percentages increased with the decrease of radiant concentrations and ranged from $(0.0$ to $68.0 \%)$ and $(0.0$ to $80.0 \%$ ) at concentrations ranged from 12 to $0.375 \mathrm{ppm}$ compared to $93 \%$ and $95 \%$ in the control fed on PBW and A. craccivora, respectively.

\section{Adult emergence:}

Also, data in Table (1) show the percentages of adult emergence from the cocoons resulted from treated eggs and reared on PBW or aphid increased by the decrease of radiant concentrations. These ranged from 0.0 to $87.0 \%$ and from 0.0 to $78.0 \%$ compared to $93.0 \%$ and $98.0 \%$ from control, respectively.

Durations of immature stages of $C$. carnea resulted from eggs treated with the dose of $\mathrm{LC}_{50}$ :

Larval stage:

Table (2) demonstrates that the average larval duration resulted from eggs treated with $L C_{50}$ varied from $1^{\text {st }}$ instar to $3^{\text {rd }}$ instar larvae when fed on $P$. gossypiella eggs or A. craccivora nymphs.

First instar larvae:

The duration of $1^{\text {st }}$ instar larvae increased significantly in treated compared to untreated eggs, Table (2). The duration of larval instar averaged 3.89 and 3.9 days 
when larvae resulted from treated eggs reared on $P$. gossypiella or aphid, respectively, compared to 2.5 and 2.9 days for control larvae.

\section{Second instar larvae:}

In contrast, this duration decreased in $2^{\text {nd }}$ instar larvae to 2.6 and 3.3 days compared to 3.6 and 3.4 days when reared on PBW or aphid, respectively.

\section{Third instar larvae:}

The duration were 4.7 and 2.1 days, for treated eggs compared to 3.6 and 3.2 days for the control. These data indicate that the eggs treated with the dose of $\mathrm{LC}_{50}$ prolonged in the duration of $1^{\text {st }}$ and $3^{\text {rd }}$ larval instar but shortened the duration of $2^{\text {nd }}$ instar Table (2).

\section{Cocoon:}

The duration of cocoon increased significantly Table (2). It lasted 8.6 and 8.8 days for treated eggs and 7.3 and 6.9 days for untreated eggs with larvae fed on PBW or aphid, respectively.

The total durations, from $1^{\text {st }}$ instar larvae until emergence of adults were 19.5 and 17.8 days when eggs were treated and the hatched larvae fed on PBW eggs and aphid nymphs, respectively. The respective durations for the control were 16.9 and 15.9 days.

\section{Larval food consumption:}

The mean numbers of the two prey species consumed showed significant differences between $1^{\text {st }}$ instar larvae hatched from treated eggs and control larvae. The mean numbers of prey individuals consumed by $1^{\text {st }}$ instar larvae of Chrysoperla resulted from eggs treated with $\mathrm{LC}_{50}$ dose were 27.6 eggs of PBW and 18.9 aphid nymphs. The respective consumed prey in the control larvae were 38.5 and 31.3 Table (3). This fact indicates 27 and $42 \%$ reduction in larval consumption of eggs and nymphs, respectively.

In $2^{\text {nd }}$ instar larvae the differences in consumption were highly significant. The consumptions were 39.3 eggs and 23.5 nymphs in larvae resulted from treated eggs whereas the respective consumptions were 77.3 and 65.6 in the control larvae. The same results were found in the $3^{\text {rd }}$ larval instar.

Mandour (2009) recorded similar result and stated that development of C. carnea was spinosad concentration-dependent, the larval, pupal and total larval plus pupal periods lasted 3,1 and 4 days longer compared to control with reduction in cocoons resulted. Vinuela et al. (2001) found that 13 different pesticides induced only slight reduction in percent of egg-hatch in C. carnea. Medina et al. (2003) observed that spinosad shortened the life span of C. carnea, and Yoo and Kim (2000) observed a reduction in fecundity of predatory mites. In contrast, several parasitoid wasps 
showed some sensitivity to spinosad (Williams et al. 2003). Schneider et al. (2004) reported a decrease in adult emergence and longevity of the endoparasitoid, Hyposoter didymator (Thunberg) treated with spinosad, 14 out of 15 studies reported some sort of sublethl effects on parasitoids following treatment with spinosad (Williams et al. 2003). Dutton et al. (2003) also found that developmental period of $C$. carnea lasted longer when larvae were fed upon Bt-contaminated Spodoptera littoralis larvae.

\section{Ovipositonal period:}

Table (3) showed that the ovipostion period and longevity of $C$. carnea females and males resulted from eggs treated with $\mathrm{LC}_{50}$ dose were slightly shorter than those resulted from untreated eggs. The predator female and male longevities were slightly longer when immature stages resulted from treated or untreated eggs were fed on aphid nymphs than on PBW eggs.

The pre ovipostion, ovipostion, post ovipostion periods and longevity were 3.7, 8.6, 0.3 and 12.5 days, respectively for female resulted from treated eggs compared to $2.6,12.0,2.3$ and 16.9 days/ for females resulted from untreated eggs when immature stages were reared on PBW eggs. The respective values in females when immature stages were reared on aphid were 2.1, 10.3, 1.6 and 14.1 days/ (treated eggs) compared to $1.6,14.7,2.3$ and 18.6 days (untreated eggs).

\section{Female fecundity:}

The average number of eggs laid/ female and percentage of hatchability decreased when the predator resulted from treated eggs compared to untreated one. On the other hand the number of deposited eggs and \% hatchability increased when $C$. carnea was reared on PBW eggs compared to aphid. The mean numbers of deposited eggs were 69.0 and 58.0 eggs/ female resulted from treated eggs and reared on PBW eggs and aphid, respectively, compared to 158.0 and 117.0 eggs/ female resulted from untreated eggs and reared on PBW and aphid, respectively, Table (4). Galvan et al. (2005) reported that when treated females of Harmonia oxyridis with indoxcarb and spinosad reduced survival, fecundity and fertility. 
706 EFFECT OF RADIANT INSECTICIDE ON THE BIOLOGY AND EGG'S HATCHABILTYY OF CHRYSOPERLA CARNEA (STEPHENS) (NEUROPTERA: CHRYSOPIDAE)

Table 1. Effect of different concentrations of Radiant on hatchability, larval and adult stages of C. carnea reared on Pectinophora gossypiella eggs and Aphid craccivora nymphs.

\begin{tabular}{|c|c|c|c|c|c|c|c|}
\hline \multirow[b]{2}{*}{$\begin{array}{l}\text { Conc. } \\
\text { ppm }\end{array}$} & \multicolumn{4}{|c|}{ P. gossypiella } & \multicolumn{3}{|c|}{ Aphis craccivora } \\
\hline & $\begin{array}{c}\text { No. of } \\
\text { eggs } \\
\text { observed }\end{array}$ & $\begin{array}{c}\% \text { egg } \\
\text { hatched }\end{array}$ & $\begin{array}{l}\% \text { larval } \\
\text { reached } \\
\text { to cocoon }\end{array}$ & $\begin{array}{c}\% \text { adult } \\
\text { emergence }\end{array}$ & $\begin{array}{c}\text { No. of } \\
\text { eggs } \\
\text { observed }\end{array}$ & $\begin{array}{c}\% \text { larval } \\
\text { reached } \\
\text { to cocoon }\end{array}$ & $\begin{array}{c}\% \text { adult } \\
\text { emergence }\end{array}$ \\
\hline 12 & 60 & 0.0 & 0.0 & 0.0 & 60 & 0.0 & 0.0 \\
\hline 6 & 60 & 18.3 & 5.0 & 0.0 & 60 & 23.17 & 7.0 \\
\hline 3 & 60 & 53.6 & 40.6 & 53.0 & 60 & 60.6 & 56.3 \\
\hline 1.5 & 60 & 58.0 & 63.6 & 57.5 & 60 & 65.3 & 61.54 \\
\hline 0.75 & 60 & 68.3 & 60.0 & 69.3 & 60 & 71.6 & 65.0 \\
\hline 0.375 & 60 & 83.3 & 68.0 & 87.0 & 60 & 80.0 & 78.0 \\
\hline Control & 30 & 98.0 & 93.0 & 95.0 & 30 & 95.0 & 98.0 \\
\hline
\end{tabular}

Table 2. Durations of immature stages of $C$. carnea resulted from eggs treated with $\mathrm{LC}_{50}$ dose (1.875 ppm.) and untreated eggs.

\begin{tabular}{|c|c|c|c|c|c|c|c|c|}
\hline \multirow{3}{*}{ Instars } & \multicolumn{8}{|c|}{ Duration (days \pm S.E.) } \\
\hline & \multicolumn{4}{|c|}{ P. gossypiella } & \multicolumn{4}{|c|}{ Aphid } \\
\hline & Treated & Untreated & LSD & $\mathrm{P}$ & Treated & Untreated & LSD & $\mathbf{P}$ \\
\hline $1^{\text {st }}$ instar & $\begin{array}{c}3.89 \pm 0.2 a \\
(3-4) \\
\end{array}$ & $\begin{array}{c}2.5 \pm 0.1 b \\
(2-3) \\
\end{array}$ & 0.48 & ** & $\begin{array}{c}3.9 \pm 0.3 a \\
(3-5)\end{array}$ & $\begin{array}{c}2.9 \pm 0.1 b \\
(2-3)\end{array}$ & 0.45 & ** \\
\hline $2^{\text {nd instar }}$ & $\begin{array}{c}2.6 \pm 0.17 \mathrm{~b} \\
(2-4) \\
\end{array}$ & $\begin{array}{c}3.6 \pm 0.16 a \\
(3-4) \\
\end{array}$ & 0.55 & ** & $\begin{array}{c}3.3 \pm 0.1 a \\
(3-4)\end{array}$ & $\begin{array}{c}3.4 \pm 0.3 a \\
(3-4)\end{array}$ & 0.35 & ** \\
\hline $3^{\text {rd }}$ instar & $\begin{array}{c}4.7 \pm 0.1 \mathrm{a} \\
(3-5) \\
\end{array}$ & $\begin{array}{c}3.6 \pm 0.21 b \\
(3-4)\end{array}$ & 0.43 & * & $\begin{array}{c}2.1 \pm 0.2 b \\
(2-3)\end{array}$ & $\begin{array}{c}3.2 \pm 0.1 \mathrm{a} \\
(3-4)\end{array}$ & 0.22 & *** \\
\hline Cocoon & $\begin{array}{c}8.3 \pm 0.4 a \\
(7-9) \\
\end{array}$ & $\begin{array}{c}7.3 \pm 0.36 \mathrm{~b} \\
(6-8)\end{array}$ & 0.76 & * & $\begin{array}{c}8.5 \pm 0.5 a \\
(7-9)\end{array}$ & $\begin{array}{c}6.4 \pm 0.4 b \\
(6-7)\end{array}$ & 0.58 & *** \\
\hline Total & $\begin{array}{c}19.5 \pm 1.4 \\
(16-21)\end{array}$ & $\begin{array}{c}16.9 \pm 0.6 \\
(14-18)\end{array}$ & 0.58 & $* * *$ & $\begin{array}{c}17.8 \pm 2.3 a \\
(15-19)\end{array}$ & $\begin{array}{c}15.9 \pm 1.3 b \\
(14-17)\end{array}$ & 1.61 & * \\
\hline
\end{tabular}


Table 3. Average number of $P$. gossypiella eggs and aphids consumed by different instars of $C$. carnea resulted from eggs treated with $L_{50}$ dose of Radiant and untreated eggs.

\begin{tabular}{|c|c|c|c|c|c|c|c|c|c|}
\hline \multirow{2}{*}{ Instars } & \multicolumn{7}{|c|}{ Consumption } \\
\cline { 2 - 10 } & \multicolumn{7}{|c|}{ P. gossypiella } & Aphid \\
\cline { 2 - 10 } & Treated & Untreated & LSD & P & Treated & Untreated & LSD & P \\
\hline $1^{\text {st }}$ instar & $27.6 \pm 0.1 \mathrm{~b}$ & $38.5 \pm 1.17 \mathrm{a}$ & 3.58 & $* *$ & $18.9 \pm 0.6 \mathrm{~b}$ & $31.3 \pm 0.6 \mathrm{a}$ & 2.26 & $* * *$ \\
\hline $2^{\text {nd }}$ instar & $39.3 \pm 0.4 \mathrm{~b}$ & $77.3 \pm 0.3 \mathrm{a}$ & 0.57 & $* * *$ & $23.5 \pm 0.4 \mathrm{~b}$ & $65.6 \pm 0.58 \mathrm{a}$ & 1.76 & $* * *$ \\
\hline $3^{\text {rd }}$ instar & $88.67 \pm 0.3 \mathrm{~b}$ & $120.3 \pm 0.5 \mathrm{a}$ & 0.98 & $* * *$ & $107.0 \pm 1.6 \mathrm{~b}$ & $183.33 \pm \mathrm{a}$ & 9.16 & $* * *$ \\
\hline $\begin{array}{c}\text { Total } \\
\text { immature } \\
\text { stage }\end{array}$ & $151.57 \pm 0.5 \mathrm{~b}$ & $232.3 \pm 2.4 \mathrm{a}$ & 2.41 & $* * *$ & $159.3 \pm 0.7 \mathrm{~b}$ & $280.0 \pm 2.07 \mathrm{a}$ & 5.21 & $* * *$ \\
\hline
\end{tabular}

Table 4. Ovipostional period, fecundity, longevity of C. carnea adult resulted from eggs treated with Radiant ( $\mathrm{LC}_{50}$ dose).

\begin{tabular}{|c|c|c|c|c|c|c|c|c|}
\hline \multirow{2}{*}{ prey } & & \multirow{2}{*}{$\begin{array}{l}\text { Pre-ovi } \\
\text { (Days) }\end{array}$} & \multirow{2}{*}{$\begin{array}{c}\text { Ovipostion } \\
\text { (Days) }\end{array}$} & \multirow{2}{*}{$\begin{array}{l}\text { Post-ovi } \\
\text { (Days) }\end{array}$} & \multirow{2}{*}{$\begin{array}{c}\text { Total eggs } \\
\text { laid }\end{array}$} & \multirow{2}{*}{$\begin{array}{c}\% \\
\text { hatchability }\end{array}$} & \multicolumn{2}{|c|}{$\begin{array}{c}\text { longevity } \\
\text { (Days) }\end{array}$} \\
\hline & & & & & & & 우 & 8 \\
\hline \multirow{6}{*}{ 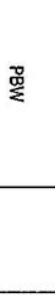 } & Treated & $3.7 \pm 0.2 \mathrm{a}$ & $8.6 \pm 0.5 b$ & $0.3 \pm 0.1 b$ & $69.0 \pm 3.1 \mathrm{~b}$ & 61 & $12.3 \mathrm{a}$ & 7.5 \\
\hline & Untreated & $2.6 \pm 0.2 b$ & $12.0 \pm 0.3 a$ & $2.3 \pm 0.1 \mathrm{a}$ & $158.0 \pm 2.6 \mathrm{a}$ & 93 & $16.8 \mathrm{~b}$ & 11.3 \\
\hline & LSD & 0.45 & 0.53 & 0.57 & 6.60 & & 0.55 & NS \\
\hline & $\mathrm{P}$ & $* *$ & $* * *$ & $* * *$ & $* * * *$ & & ** & \\
\hline & & \multirow[b]{2}{*}{ Pre-ovi } & \multirow[b]{2}{*}{ ovipostion } & \multirow[b]{2}{*}{ Post-ovi } & \multirow{2}{*}{$\begin{array}{c}\text { Total eggs } \\
\text { laid }\end{array}$} & \multirow{2}{*}{$\begin{array}{c}\% \\
\text { hatchability }\end{array}$} & \multicolumn{2}{|c|}{ Longevity } \\
\hline & & & & & & & 오 & 8 \\
\hline \multirow{4}{*}{ 章 } & Treated & $2.1 \pm 0.1$ & $10.3 \pm 0.3 \mathrm{~b}$ & $1.6 \pm 0.2 \mathrm{~b}$ & $58.0 \pm 0.36 a$ & 43.0 & $14.0 \pm 0.2 \mathrm{~b}$ & $10.6 \pm 0.4 b$ \\
\hline & Untreated & $1.6 \pm 0.13$ & $14.7 \pm 0.61 \mathrm{a}$ & $2.3 \pm \mathrm{a}$ & $117.0 \pm \mathrm{b}$ & 87.0 & $18.6 \pm 0.5 a$ & $12.5 \pm 0.2$ \\
\hline & LSD & NS & 0.97 & 0.68 & 12.20 & & 0.97 & 0.57 \\
\hline & $P$ & & *** & $* * *$ & $* * *$ & & $* * *$ & $* *$ \\
\hline
\end{tabular}




\section{REFERENCES}

1. Brickle, D.L., S.G. Turnipseed and M.J. Sullivan. 2001. Efficacy of insecticides of different chemistries against Helicoverpa Zea (Lepidopter : Noctuidae) in transgenic Bacillus thuringiensis and conventional cotton. J. Econ. Entomol., 94:86-92.

2. Duncan, D.B. 1955. Multiple range and multiple $F$ tests. Biometrics, 11:1-42.

3. Dutton, A., H. Klein, J. Romeis and F. Bigler. 2003. Prey-mediated effects of Bacillus thuringiensis spray on the predator Chrysoperla carnea in maize. Biol. Control, 26:209-215.

4. Galvan, T.L., R.L. Koch and W.D. Hutchion. 2005. Effect of spinosad and indoxcarb on survival, development, and reproduction of the multicolored Asian lady beetle (Coleoptera: Coccinellidae). Biol. Control, 34: 108-114.

5. Mandour, N.S. 2009. Influence of spinosad on immature and adult stages of Chrysoperla carnea (Stephens) (Neuropter:Chrysopidae). BioControl, 54:93102.

6. Medina, P., F. Budia, G. Smagghe and E. Vinuela. 2001. Activity of spinosad, diflubenzuron and azadirachtin on eggs and pupae of Chrysoperla carnea (Stephens) under laboratory conditions. Biocontrol Sci. Technol., 11:597-610.

7. Medina, P., F. Budia, L. Tirry and E. Vinuela. 2003. Toxicity and absorption of azadrachtin, diflubenzuron, pyriproxfen and tebufenozide after direct spray in predator larvae of Chrysoperla carnea (Stephens) (Neuroptera: Chrysopidae). Environ. Entomol., 32:196-203.

8. Medina, P., F. Budia Del Estal P. and E.Vinuela. 2003. Effect of three modern insecticides, pyriproxfen, spinosad and tebufenozid on survival and reproduction of Chrysoperla carnea adults. Ann. Appl. Biol., 142:55-61.

9. Rashad, Amira, M. and E.D. Ammer. 1985. Mass rearing of spiny bollworm, Earias insulana (Boisd.) on semi-artificial diet. Bull. Soc. Ent. Egypt, 65:239244.

10. Schneider, M.I., G. Smagghe, S. Pineda and E.Vinuela. 2004. Action of insect growth regulators insecticides and spinosad on life history parameters and absorption in third instar larvae of the endoparasitoid Hyposoter didymtor. Biol. Control, 31:189-198. 
11. Tauber M.J., C.A. Tauber, K.M. Daane and K.S, Hagen: 2000. Commercialization of predators: recent lessons from green lacewings (Neuroptera: Chrysopidae: Chrysoperla). Am. Entomol., 46:26-38.

12. Vinuela E., M.P. Medina, M. Schneider, M. Gonzalez, F. Budia, A. Adan and P. Del Estal. 2001. Comparison of side- effects of spinosad, tebufenozide and azidirachtin on the predators Chrysoperla carnea and Podisus maculiventris and parasitoids Opius concolor and Hyposoter didymator under laboratory conditions. IOBC/W.WPS Bull., 24:25-34.

13. Wanner, K.W., B.V. Helson and B.J. Harris. 2000. Laboratory and field evaluation of spinosad against the gypsy moth, Lymantria dispar. Pest Manag. Sci., 565:855-860.

14. Williams, L., L.D. Price and V. Manriue. 2003. Toxicity of field weathered insecticides residues to Anaphes iole (Hymenoptera: Mymaridae), an egg parasitoid of Lygus lineolarias (Heteroptera:Miridae), and implications for inundative biological control. Biol. Control, 26:217-223.

15. Yoo, S.S. and S.S. Kim. 2000. Comparative toxicity of some pesticides to the predatory mite, Phytoșeiulus persimilis (Acarina : phytoseiidae) and two spotted mite Tetranychus urtica (Acarina : Tetranychidae). Korean J. Entomol., 30:235-241. 
710 EFFECT OF RADIANT INSECTICIDE ON THE BIOLOGY AND EGG'S HATCHABILTY OF CHRYSOPERLA CARNEA (STEPHENS) (NEUROPTERA: CHRYSOPIDAE)

تأثيرمبيد الرادينت علي فقس البيض وبعض الخصائص البيولوجية لاسد المن

$$
\begin{aligned}
& \text { هشام صالح شعلان ، ميرفت عبد السميع قنديل } \\
& \text { معرد بحوث وقاية النباتات - مركز البحوث الزراعية الدقي - الجيزة }
\end{aligned}
$$

تم دراسة تأثير مبيد الر ادينت علي نسبة الفقس لبيض المفترس الحشري السد المن وكنلك متابعة

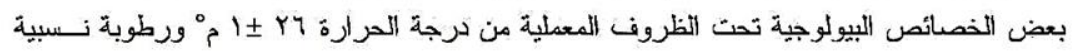

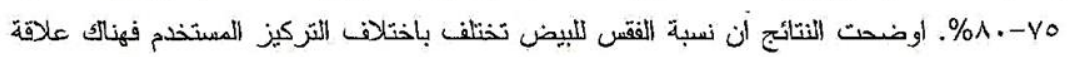

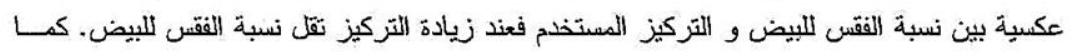

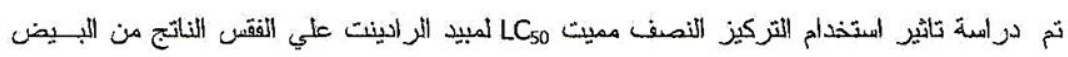

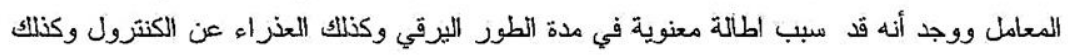

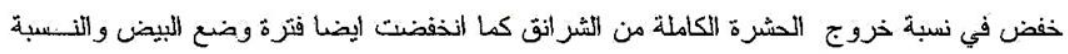

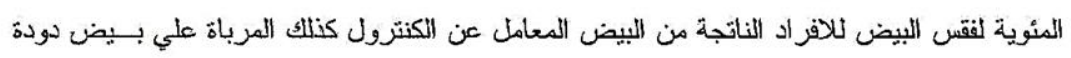

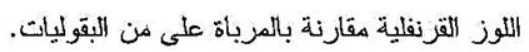

